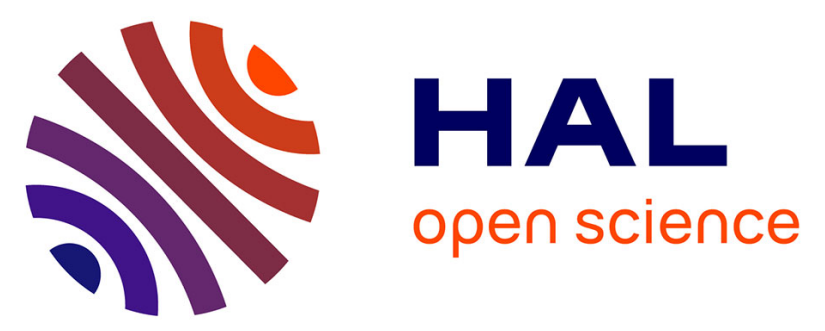

\title{
Insecticidal Activity of the Leaf Essential Oil of Peperomia borbonensis Miq . (Piperaceae) and Its Major Components against the Melon Fly Bactrocera cucurbitae (Diptera: Tephritidae)
}

Emmanuelle Dorla, Anne Gauvin-Bialecki, Zoé Deuscher, Agathe Allibert, Isabelle Grondin, Jean-Philippe Deguine, Philippe Laurent

\section{To cite this version:}

Emmanuelle Dorla, Anne Gauvin-Bialecki, Zoé Deuscher, Agathe Allibert, Isabelle Grondin, et al.. Insecticidal Activity of the Leaf Essential Oil of Peperomia borbonensis Miq . (Piperaceae) and Its Major Components against the Melon Fly Bactrocera cucurbitae (Diptera: Tephritidae). Chemistry and Biodiversity, 2017, 14 (6), pp.e1600493. 10.1002/cbdv.201600493 . hal-01624992

\section{HAL Id: hal-01624992 \\ https://hal.univ-reunion.fr/hal-01624992}

Submitted on 27 Oct 2017

HAL is a multi-disciplinary open access archive for the deposit and dissemination of scientific research documents, whether they are published or not. The documents may come from teaching and research institutions in France or abroad, or from public or private research centers.
L'archive ouverte pluridisciplinaire HAL, est destinée au dépôt et à la diffusion de documents scientifiques de niveau recherche, publiés ou non, émanant des établissements d'enseignement et de recherche français ou étrangers, des laboratoires publics ou privés. 


\title{
Insecticidal Activity of the Leaf Essential Oil of Peperomia borbonensis MIQ. (Piperaceae) and Its Major Components against the Melon Fly Bactrocera cucurbitae (Diptera: Tephritidae)
}

\author{
Emmanuelle Dorla, ${ }^{a}$ Anne Gauvin-Bialecki, ${ }^{a}$ Zoé Deuscher, ${ }^{a}$ Agathe Allibert, ${ }^{\mathrm{b}}$ Isabelle Grondin, ${ }^{\mathrm{a}}$ \\ Jean-Philippe Deguine, ${ }^{\mathrm{b}}$ and Philippe Laurent*a \\ a'Laboratoire de Chimie des Substances Naturelles et des Sciences des Aliments (LCSNSA), Université de La Réunion, \\ Avenue René Cassin-CS, 92003-97744 Saint-Denis Cedex 9, France, e-mail: philippe.laurent@univ-reunion.fr

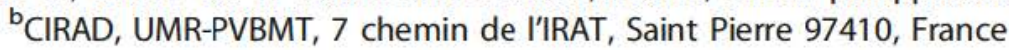

\begin{abstract}
The essential oil from the leaves of Peperomia borbonensis from Reunion Island was obtained by hydrodistillation and characterized using GC-FID, GC/MS and NMR. The main components were myristicin (39.5\%) and elemicin (26.6\%). The essential oil (EO) of Peperomia borbonensis and its major compounds (myristicin and elemicin), pure or in a mixture, were evaluated for their insecticidal activity against Bactrocera cucurbitae (Diptera: Tephritidae) using a filter paper impregnated bioassay. The concentrations necessary to kill $50 \%\left(L C_{50}\right)$ and $90 \%\left(L C_{90}\right)$ of the flies in three hours were determined. The $L C_{50}$ value was $0.23 \pm 0.009 \mathrm{mg} /$ $\mathrm{cm}^{2}$ and the $L C_{90}$ value was $0.34 \pm 0.015 \mathrm{mg} / \mathrm{cm}^{2}$ for the EO. The median lethal time $\left(L T_{50}\right)$ was determined to compare the toxicity of EO and the major constituents. The EO was the most potent insecticide $\left(L T_{50}=98 \pm 2 \mathrm{~min}\right)$, followed by the mixture of myristicin and elemicin (1.4:1) $\left(L T_{50}=127 \pm 2 \mathrm{~min}\right)$ indicating that the efficiency of the EO is potentiated by minor compounds and emphasizing one of the major assets of EOs against pure molecules.
\end{abstract}

\section{Introduction}

The evolution of crop protection has relied on various concepts, one of which is integrated pest management, which came into widespread use in the second half of the 20th century. Nowadays, the issue of crop protection is to move from an agrochemical-based curative approach to an approach to prevent damage caused by crop pests, based on more balanced and durable ecological management of agroecosystems. ${ }^{[1]}$ A strong tendency has led researchers and practitioners to techniques aiming at reducing the use of chemical pesticides, especially because of economic costs, as well as sanitary and environmental constraints (efficiency shift, growers and consumers exposed to toxicity, environmental pollution). This reduction in the use of pesticides has been accompanied by the development of agroecological solutions, based on scientific principles of ecology, as well as the development of biocontrol techniques. Biocontrol aims at privileging the use of mechanisms and natural interactions, by the means of different types of substances: natural substances, macroorganisms, microorganisms and chemical mediators. Among the natural substances, plants and plant extracts are often used as alternatives to classical agropharmaceutical products.

The ability of plants to produce secondary metabolites having biocidal and/or repellent activities represents one of major mechanisms of defense, when facing arthropod bioagressors. ${ }^{[2]}$ In addition, the phenomenon of resistance observed with many synthetic pesticides will develop more slowly with the use of plant extracts such as essential oils due to their complex mixtures of constituents. ${ }^{[3]}$ In recent years, particular interest has been attributed to essential oils due to their biological activities, ${ }^{[4]}$ such as antimicrobial ${ }^{[5]}$ and insecticidal activities. ${ }^{[6][7]}$ Essential oils are an alternative strategy to control pest and develop new biopesticides. ${ }^{[6][7]}$ The genera able to produce essential oils are distributed in a limited number of families, such as Myrtaceae, Lauraceae, Rutaceae, Lamiaceae, Asteraceae, Apiaceae, Cupressaceae, Poaceae, Zingiberaceae and Piperaceae. ${ }^{[8]}$

The Piperaceae family (Order Piperales), widely distributed in tropical and subtropical regions, consists of five genera among which Peperomia is one of the 
most important in terms of the number of species (1700 species). ${ }^{[9]}$ Several species of the genus Peperomia possess many biological activities (anti-inflammatory, ${ }^{[10]}$ antipyretic, ${ }^{[11]}$ and antimicrobial ${ }^{[12]}$. The genus Peperomia is also found throughout Réunion Island (Indian Ocean), known as a biodiversity hotspot and characterized by a high rate of endemic species. In order to contribute to better knowledge of the genus Peperomia, we focused our study on the endemic species Peperomia borbonensis MiQ., traditionally used by farmers to control arthropod infestations. No previous study was found concerning this plant and more broadly concerning the biocontrol of insects by the genus Peperomia.

Bactrocera cucurbitae (Diptera: Tephritidae) is widely distributed throughout tropical Asia, the south Pacific, Australia and in the Indian Ocean (Africa, Mauritius, Seychelles, Réunion Island). ${ }^{[13]}$ This insect is considered as the major pest of Réunion Island's agricultural activities ${ }^{[13]}$ and as a world-wide pest of economic importance. ${ }^{[14]}$ The control of this fly is principally based on the use of chemical insecticides, but the literature reports an increasing interest in biological control in recent years. ${ }^{[15][16]}$ Some studies have been carried on the insecticidal activity of essential oils against Tephritidae species such as Ceratitis capitata ${ }^{[17-19]}$ and, in particular, against the Bactrocera species. ${ }^{[20][21]}$ In addition, several studies have shown the insecticidal activity of crude plant solvent extracts on B. cucurbitae. ${ }^{[22][23]}$

In the present investigation, the leaf essential oil (EO) from Peperomia borbonensis was tested for its insecticidal activity against the melon fly, Bactrocera cucurbitae (Diptera: Tephritidae). The composition of the $P$. borbonensis EO was also evaluated by GC/MS, GC-FID and NMR. The main components were also tested against $B$. cucurbitae.

\section{Results and Discussion}

Peperomia borbonensis Essential Oil

Hydrodistillation of the fresh leaves of Peperomia borbonensis gave a greenish-yellow EO with a strong odor (yield $=0.46 \% w / w$ ). GC/MS and GC-FID were used to determine its composition. It should be mentioned that one unusual compound that could not be identified by computer matching with MS libraries (Wiley 7, NIST 02) and linear retention indices reported in the literature ${ }^{[24]}$ was isolated by repeated column chromatography and identified by ${ }^{1} \mathrm{H}$ - and ${ }^{13} \mathrm{C}-\mathrm{NMR}$ as alismol, a sesquiterpene alcohol. ${ }^{[25]}$ NMR data were listed in the experimental section. Table 1 shows the different identified constituents, their percentage composition and linear retention indices (LRI). All the constituents were grouped by chemical classes and were listed inside each group according to their elution order on the apolar SPB-5 column. Twenty-one components accounting for $97.0 \%$ of the total EO composition were identified.

The EO was characterized by a high amount of the two phenylpropanoids, myristicin (39.5\%) and elemicin (26.6\%) (Fig. 1).

The EO was also distinguishable by significant ratios of decanal (7.3\%) and 10-methyl-3,4,5,8,9,10hexahydrooxecin-2-one (7.3\%), a macrocyclic lactone tentatively identified by its mass spectrum. Although quantitatively lower (13.0\%), several sesquiterpenes were clearly present: ten sesquiterpene hydrocarbons

Table 1. Constituents identified from the essential oil of Peperomia borbonensis

\begin{tabular}{|c|c|c|}
\hline Compound & $L R I^{a}$ & Content $[\%]^{\mathrm{b}}$ \\
\hline \multicolumn{3}{|l|}{ Alcohols (1.0\%) } \\
\hline 1-Decanol & 1271 & 1.0 \\
\hline \multicolumn{3}{|l|}{ Aldehydes (8.5\%) } \\
\hline Decanal & 1206 & 7.3 \\
\hline Dodecanal & 1409 & 1.2 \\
\hline \multicolumn{3}{|l|}{ Esters $(0.6 \%)$} \\
\hline 1-Octenyl acetate & 1109 & 0.6 \\
\hline \multicolumn{3}{|l|}{ Monoterpene hydrocarbons $(0.1 \%)$} \\
\hline$\beta$-Phellandrene & 1034 & 0.1 \\
\hline \multicolumn{3}{|l|}{ Oxygenated monoterpenes $(0.4 \%)$} \\
\hline Linalool & 1100 & 0.3 \\
\hline Neryl acetate & 1347 & 0.1 \\
\hline \multicolumn{3}{|l|}{ Sesquiterpene hydrocarbons (12.4\%) } \\
\hline$\delta$-Elemene & 1344 & 4.9 \\
\hline$\beta$-Elemene & 1401 & 1.6 \\
\hline (E)- $\beta$-Caryophyllene & 1435 & 0.5 \\
\hline$\beta$-Gurjunene & 1449 & 2.2 \\
\hline$\gamma$-Selinene & 1467 & 0.2 \\
\hline Valencene & 1490 & 0.6 \\
\hline Germacrene D & 1496 & 0.6 \\
\hline$\beta$-Selinene & 1503 & 1.1 \\
\hline$(E, Z)-\alpha$-Farnesene & 1510 & 0.4 \\
\hline trans- $\beta$-Guaiene & 1519 & 0.3 \\
\hline \multicolumn{3}{|l|}{ Oxygenated sesquiterpenes $(0.6 \%)$} \\
\hline Alismol $^{c}$ & 1643 & 0.6 \\
\hline \multicolumn{3}{|l|}{ Phenylpropanoids (66.1\%) } \\
\hline Myristicin & 1531 & 39.5 \\
\hline Elemicin & 1559 & 26.6 \\
\hline \multicolumn{3}{|l|}{ Miscellaneous (7.3\%) } \\
\hline $\begin{array}{l}\text { 10-Methyl-3,4,5,8,9, 10-hexahydro- } \\
\text { oxecin-2-one }\end{array}$ & 1294 & 7.3 \\
\hline Total identified & & 97.0 \\
\hline
\end{tabular}

${ }^{a} L R I=$ Linear Retention indices were experimentally measured using homologous series of $n$-alkanes $\left(C_{8}-C_{22}\right)$. ${ }^{b}$ Percentage was obtained by FID peak area normalization without using response factors. ' Characterized by NMR data (see Experimental Section). ${ }^{\mathrm{d}}$ Tentatively identified. 
<smiles>C=CCc1cc(OC)c2c(c1)OCO2</smiles>

Myristicin<smiles>C=CCc1cc(OC)c(OC)c(OC)c1</smiles>

Elemicin

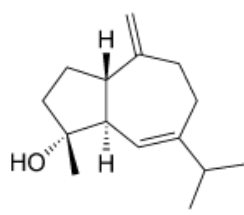

Alismol
Figure 1. Structures of myristicin and elemicin, the main components of the leaf essential oil from Peperomia borbonensis, and alismol, the NMR identified compound.

among which $\delta$-elemene (4.9\%), $\beta$-elemene (1.6\%) and $\beta$-gurjunene (2.2\%) and only one oxygenated sesquiterpene, namely alismol $(0.6 \%)$ (Fig. 1). The proportion of monoterpenes was modest with the presence of $\beta$-phellandrene (0.1\%), linalool $(0.3 \%)$ and neryl acetate $(0.1 \%)$. To the best of our knowledge, this is the first report on the composition of the EO from $P$. borbonensis.
Comparison of these results with the literature data on Peperomia species EOs revealed notable qualitative and quantitative differences. In the volatile oil of $P$. oreophila from Brazil, two rare sesquiterpenes were identified: 3-ishwarone (78.2\%) and 3-ishwarol $(0.8 \%){ }^{[26]}$ Santos et al. (2001) investigated components of the aerial parts of $P$. rupestris, also from Brazil. The main constituents in the EO were two sesquiterpene hydrocarbons: germacrene $D(15.0 \%)$ and $(E)$-caryophyllene $(9.7 \%) .{ }^{[27]}$ The investigation of the EO of $P$. galioides from Peru allowed the identification of 72 constituents from the fresh aerial parts, accounting for $93.4 \%$ of the total EO composition. epi- $\alpha$-Bisabolol (21.3\%), $\alpha$-humulene (17.3\%) and $\beta$-caryophyllene (13.1\%) were the major components of this species. The EO obtained from dried aerial parts of $P$. galioides was slightly different, as it contained epi- $\alpha$-bisabolol (15.1\%), $\alpha$-humulene (13.2\%) and $\beta$-caryophyllene

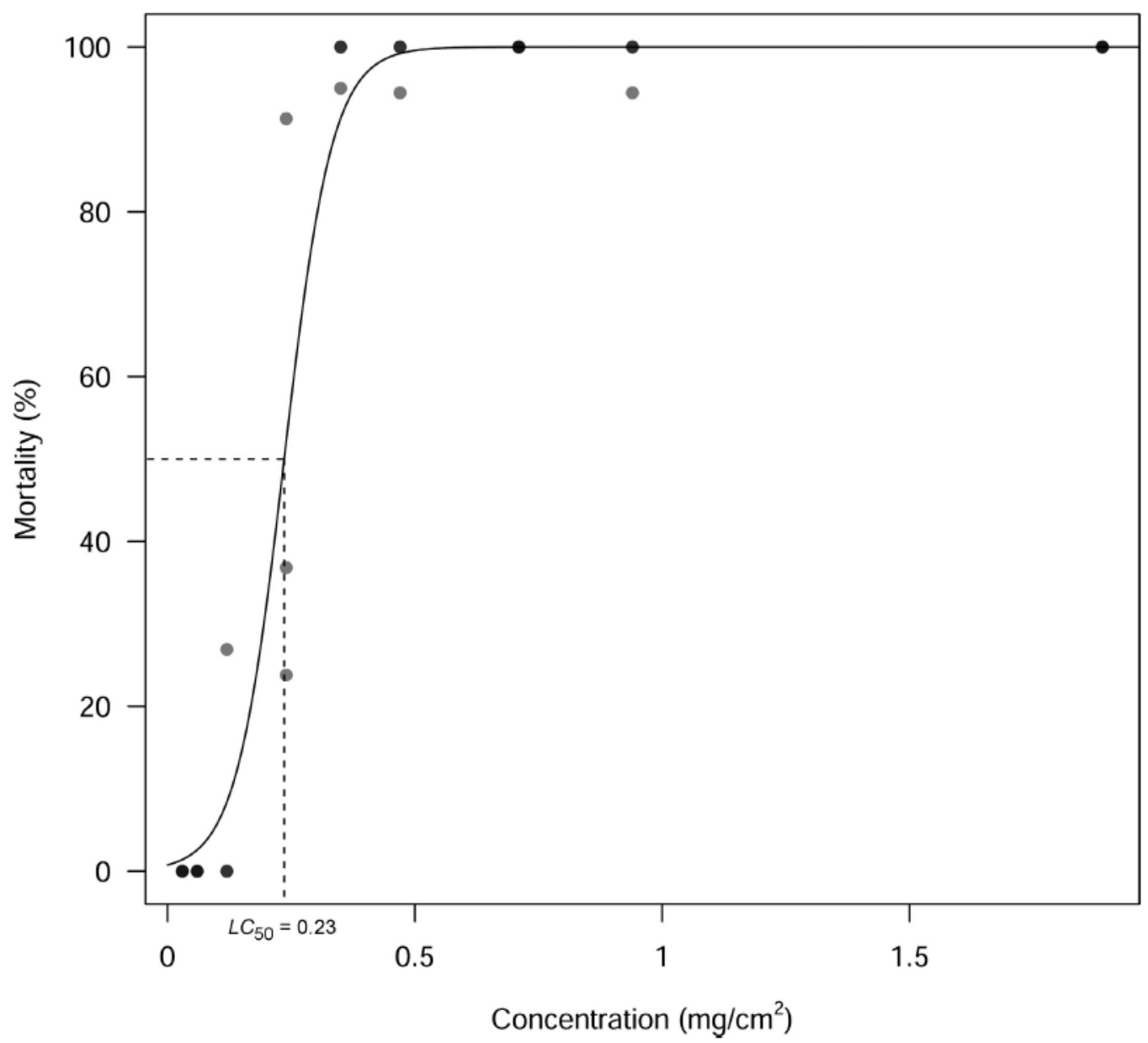

Figure 2. Toxic activity of Peperomia borbonensis essential oil on Bactrocera cucurbitae tested at different concentrations (1.89 mg/ $\mathrm{cm}^{2}, 0.94 \mathrm{mg} / \mathrm{cm}^{2}, 0.71 \mathrm{mg} / \mathrm{cm}^{2}, 0.47 \mathrm{mg} / \mathrm{cm}^{2}, 0.35 \mathrm{mg} / \mathrm{cm}^{2}, 0.24 \mathrm{mg} / \mathrm{cm}^{2}, 0.12 \mathrm{mg} / \mathrm{cm}^{2}, 0.06 \mathrm{mg} / \mathrm{cm}^{2}, 0.03 \mathrm{mg} / \mathrm{cm}^{2}$ ). All doses were replicated three times. The color code represents the number of superposed triplicate values: one grey circle corresponds to one value, one dark grey circle two values and one black circle to three values. The line represents the predicted values of a logit model (binomial distribution and logistic link function) for the essential oil. $L C_{50}$ is the lethal dose for $50 \%$ mortality of $B$. cucurbitae determined from logit analysis. 
$(16.0 \%){ }^{[28]}$ Decanal $(32.8-44.4 \%)$ and limonene (28.7 - 35.0\%) were the main components of the volatile oil of $P$. rotundifolia grown in the Amazon region. ${ }^{[29]}$

According to the literature data, molecules with a phenylpropene skeleton are generally found as minor compounds in Peperomia species EO, except in i) $P$. pellucida from Brazil for which dillapiole was the major component $\left.(37.0-55.3 \%) ;{ }^{[30}-32\right]$ ii) P. scandens, also from Brazil, which contains dillapiole and its isomer apiole in significant quantities $(8.4 \%$ and $7.1 \%$, respectively); ${ }^{[30]}$ iii) $P$. obtusifolia from Pakistan for which the phenylpropene apiole was also found in a high quantity (16.7\%). ${ }^{[33]}$ The two phenylpropenes, myristicin and elemicin, identified as the major components in P. borbonensis EO $(39.5 \%$ and $26.6 \%$, respectively), were also detected in other Peperomia species, but in lower proportions: P. pellucida $(0.3 \%$ and $11.3 \%$ ) and P. macrostachya (7.6\%) for myristicin $^{[32][34]}$ and

P. pellucida

$(0.2 \%)$ $P$. macrostachya $(1.6 \%)^{[32]}$ and $P$. circinnata $(11.5 \%)^{[31]}$ for elemicin. Such high ratios of these allylbenzenes were observed more particularly in the EO of Piper species where the myristicin content accounted for $20.3 \%, 25.6 \%$ and $65.2 \%$ of the composition of Piper hostmaniannum, Piper permucronatum and Piper sarmentosum, respectively. In Piper hostmaniannum and Piper sarmentosum, the elemicin content was $1.7 \%$ and $1.5 \%{ }^{[35][36]}$

To the best of our knowledge, no macrocyclic lactone was recovered in EOs obtained from both Piper and Peperomia.

\section{Insecticidal Properties of Peperomia borbonensis}

Essential Oil on Bactrocera cucurbitae

The toxicity of Peperomia borbonensis EO and of its major components, alone or in combination, was

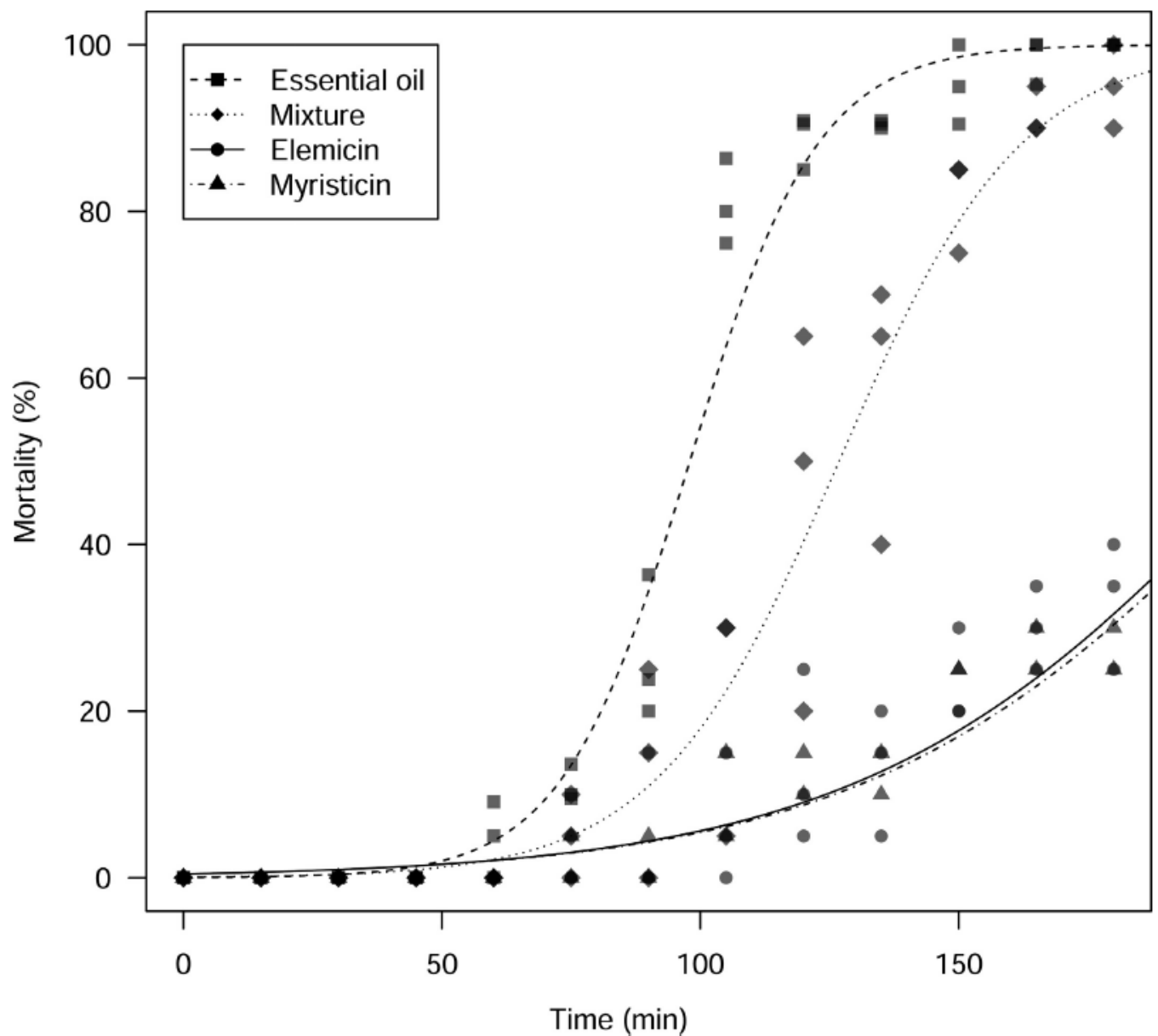

Figure 3. Toxic activity of essential oil of Peperomia borbonensis ( $\square$ ), myristicin ( $\mathbf{\Delta})$, elemicin $(\boldsymbol{\bullet})$ and the mixture $(\bullet)$. The amount of myristicin and elemicin used alone or in mixture was fixed according to their ratio in the EO obtained by GC-FID. Each product was tested three times. The color code represents the number of superposed triplicate values: one grey circle corresponds to one value, one dark grey circle to two values and one black circle to three values. Each line represents the predicted values of a logit model (binomial distribution and logistic link function) for each product. 
determined for Bactrocera cucurbitae. The EO seems to act as a neurotoxin. Indeed, after contact with the EO or the two major compounds, flies had convulsions and were knocked down. Results obtained for lethal concentration bioassays are shown in Fig. 2. Mortality was observed from the concentration of $0.12 \mathrm{mg} / \mathrm{cm}^{2}$. The $L C_{50}$ and $L C_{90}$ values were calculated using logit analysis. The $L C_{50}$ and $L C_{90}$ values for the exposure period of $180 \mathrm{~min}$ were $0.23 \pm 0.009 \mathrm{mg} / \mathrm{cm}^{2}$ and $L C_{90}$ of $0.34 \pm 0.015 \mathrm{mg} / \mathrm{cm}^{2}$, respectively. When elemicin and myristicin were tested separately according to the ratio found in the EO, the mortality did not reach $40 \%$ at the end of the experiment (180 $\mathrm{min}$ ).

The two curves did not differ significantly (Fig. 3), was congruent with median lethal time values $\left(L T_{50}\right)$ calculated for each individual compound, myristicin $\left(L T_{50}=213 \pm 8 \mathrm{~min}\right)$ and elemicin $\left(L T_{50}=210\right.$ $\pm 6 \mathrm{~min})$.

However, the amount of myristicin used in this experiment was higher than elemicin $\left(0.14 \mathrm{mg} / \mathrm{cm}^{2}\right.$ and $0.09 \mathrm{mg} / \mathrm{cm}^{2}$, respectively), to match the EO ratio. This may indicate that elemicin is more active on Bactrocera cucurbitae than myristicin. Furthermore, a synergistic effect was observed between these two molecules since the theoretical addition of the separate activities was significantly below the activity of the mixture in the same ratio $(P<0.001)$ (Fig. 4).

Myristicin and elemicin contributed largely to the toxicity of the EO, as shown in Fig. 3, but not enough to explain the entire insecticidal activity of the EO. Indeed, the toxic activity curve of the phenylpropanoid mixture differed significantly from that of the $P$. borbonensis EO $(P=0.00153)$. The essential oil was more effective ( $\left.L T_{50}=98 \pm 2 \mathrm{~min}\right)$ than the mixture of myristicin and elemicin $\left(L T_{50}=127 \pm 2 \mathrm{~min}\right)$. These results indicate that the efficiency of $P$. borbonensis EO on Bactrocera cucurbitae is potentiated by some minor compounds. These constituents seem to be necessary to achieve full toxicity. Some of the identified minor components have been reported to

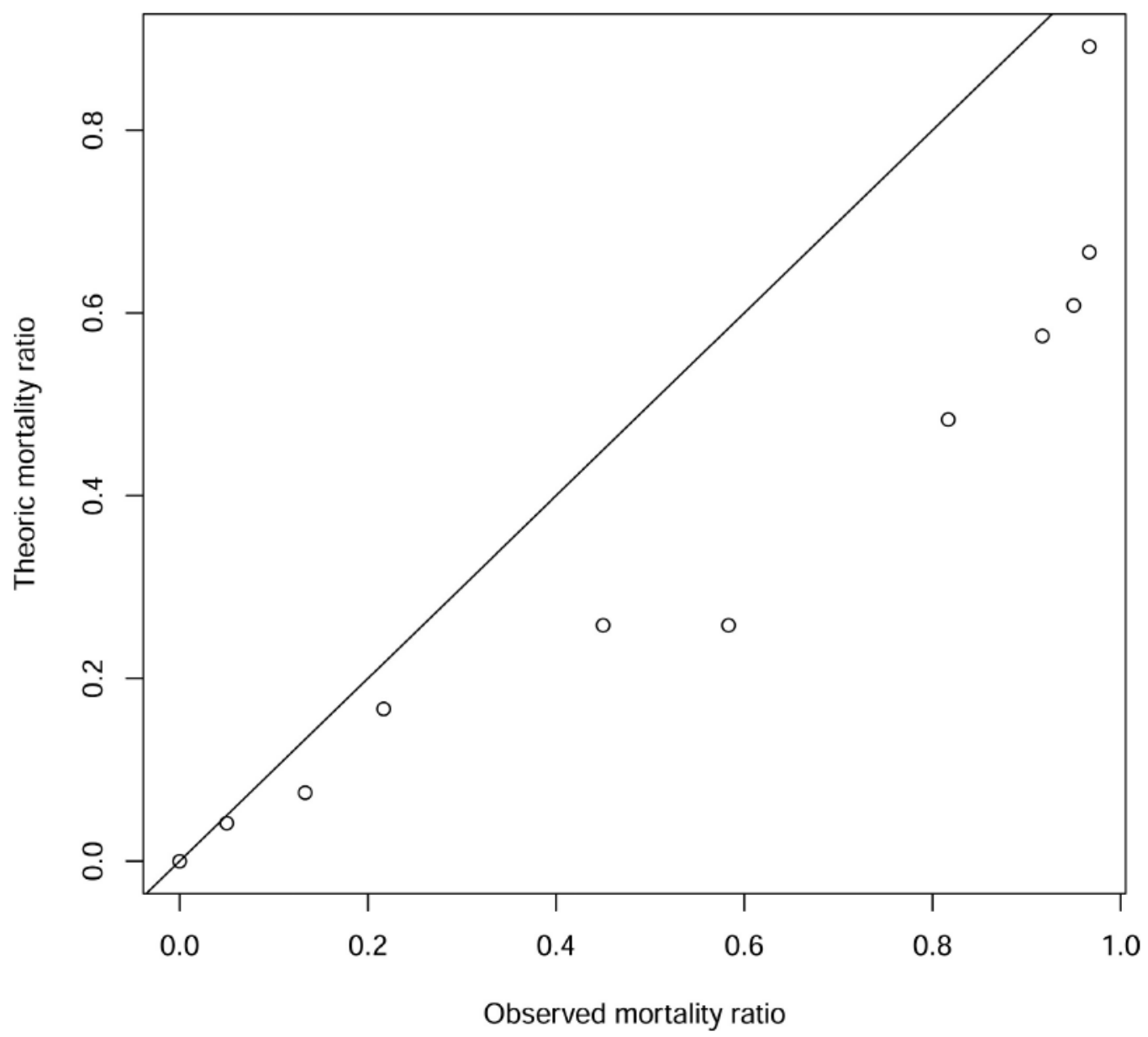

Figure 4. Comparison of the ratios of mortality obtained for the mixture ( $x$ axis) and theoretical sum ( $y$ axis) of the two products tested separately for different time exposure. The difference between the ratios was tested by a Wilcoxon signed rank test $(P<0.001)$. Each circle corresponds to the observed and theoretical mortalities ratio at a given time. The solid line represents the equal ratios. 
possess insecticidal activity against pest such as the monoterpenes $\beta$-phellandrene against German cockroach, $^{[37]}$ linalool against fruit flies, ${ }^{[20]}$ and the sesquiterpene $\beta$-selinene against the vinegar fly. ${ }^{[38]}$ However non-insecticide minor compounds could also potentiate the effect of myristicin and elemicin; this effect is still to be determined and evaluated. Among these compounds, 10-methyl-3,4,5,8,9,10-hexahydrooxecin-2-one could be a candidate since some macrocyclic lactones are known to have insecticidal activity (i.e., 'Spinosad'). In future investigations, the formal identification of this compound will be verified and its biological activity evaluated.

In recent years, particular attention has been paid to essential oils and their constituents regarding their efficiency in controlling pests. ${ }^{[6]}$ Monoterpenoids and sesquiterpenoids have been reported to possess biological activities against pests such as Tribolium castaneum, Lasioderma serricorne or Attagenus piceus. ${ }^{[39][40]}$ Although their mode of action has not been well studied, some experiments have demonstrated that monoterpenoids cause insect mortality by inhibiting acetylcholinesterase enzyme activity. ${ }^{[37][41][42]}$ Substituted phenols possess also insecticidal activities and could be better toxicants than monoterpenes. ${ }^{[3]}$ The phenylpropanoids elemicin and myristicin possess anti-cholinergic activity. They act as mono-amine oxidase inhibitors and induced serotonergic neuronal cell death. ${ }^{[43]}$ They are also known to exert a psychedelic effect in humans. ${ }^{[44]}$ Studies have reported the insecticidal activity of these molecules from Piperaceae and more particularly from the Piper species. ${ }^{[45][46]}$ High toxicity of myristicin was also evaluated against Aedes aegypti $\left(L C_{50}=36 \mu \mathrm{g} / \mathrm{ml}\right),{ }^{[35]}$ Musca domestica ${ }^{[47]}$ and Blatta orientalis. ${ }^{[47]}$ Myristicin is found in the volatile oil of Piper sarmentosum (65.2\%) which possess strong antifeedant, toxicity and inhibiting development effects on Brontispa longissimi. ${ }^{[36]}$ Furthermore, this molecule possesses a synergistic effect when tested with carbamates on Musca domestica. ${ }^{[48]}$

This work showed that myristicin and elemicin, the major compounds of the $P$. borbonensis EO, have synergistic insecticidal activity on B. cucurbitae. Furthermore, this activity is potentiated by the presence of minor compounds, emphasizing one of the major assets of EOs against pure molecules; the complex nature of EOs may delay the onset of resistance in pests. The mode of action of phenylpropanoids leads us to believe that these molecules would be toxic against a large range of arthropods. Further experiments need to be performed to verify the toxicity of $P$. borbonensis EO against auxiliary insects. Nevertheless, this volatile oil could be used in an agroecological crop protection strategy against melon fly. Indeed, a study performed by Atiama-Nurbel et al. (2012) showed that maize is the most attractive plant to cucurbit fly species. ${ }^{[49]}$ The simultaneous use of maize as a border crop spotted with a natural insecticide such as Peperomia borbonensis EO and a selective attractant would have advantages against classical agropharmaceutical products and moreover be cost effective and not hazardous to the environment and human health (volatility, low toxicity to mammals, biodegradability).

\section{Conclusions}

This study is the first report of the chemical composition and the insecticidal potential of the leaf volatile oil of Peperomia borbonensis. The obtained $L C_{50}$ and $L C_{90}$ demonstrate the efficacy of the EO against Bactrocera cucurbitae. The contact toxicity is attributed to its high levels of phenylpropanoid compounds (myristicin and elemicin), which display synergistic insecticidal activity potentiated by minor compounds. This complex mixture could be used in an agroecological management strategy to fight the potential phenomenon of resistance developed by the melon fly. Hence, a specific attractant (parapheromones for example) could be mixed with the $P$. borbonensis EO and spotted on a border crop (maize for example which is naturally attractive for melon flies). This 'attract and kill' approach would lead to a rational use of the EO and a better selectivity against target insects. Further investigations are needed to measure the impact and effectiveness of this strategy.

\section{Experimental Section}

\section{Peperomia borbonensis Essential Oil}

Plant Material. The plant Peperomia borbonensis MiQ. was collected in October 2013 in La Plaine des Cafres (Réunion Island - $21^{\circ} 20^{\prime} 559 \mathrm{E} ; 55^{\circ} 35^{\prime} 512$ S) at $1695 \mathrm{~m} \pm 16 \mathrm{~m}$. The plant was identified by the botanist Jacques Fournel (University of La Réunion). An authenticated voucher specimen (No. REU12639) was deposited with the Herbarium of the University of La Réunion, France.

\section{Essential Oil Isolation}

Fresh leaves $(1300 \mathrm{~g})$ of the plant were hydrodistilled in a Clevenger modified-type apparatus for $4 \mathrm{~h}$. The oil was taken up in $\mathrm{CH}_{2} \mathrm{Cl}_{2}(>99.5 \%$, Carlo-Erba) and dried over anhydrous sodium sulfate and stored in amber glass vials $\left(+4{ }^{\circ} \mathrm{C}\right)$ until chromatographic 
analyses and bioassays. The extraction yield $(0.46 \% \mathrm{w} /$ w) was calculated on the basis of the fresh weight of the plant material.

\section{Isolation and Purification of Alismol}

The essential oil $(1.5 \mathrm{~g})$ was chromatographed on a silica gel flash column eluted successively with isohexane $(100 \mathrm{ml})$ and AcOEt $(100 \mathrm{ml})$. The AcOEt fraction containing the constituents of interest (alismol, Fig. 1), was evaporated under reduced pressure then further submitted to a column chromatography over flash silica gel with isohexane - AcOEt gradient to afford 26 fractions. The fractions were monitored by GC/MS. Frs. 11 - 13 were put together then further submitted to a RP-HPLC purification (Kinetex $5 \mu \mathrm{m} 4.6 \times 100 \mathrm{~mm}$ column; $0.7 \mathrm{ml} / \mathrm{min}$ gradient elution with $10 \% \mathrm{MeCN} /$ $\mathrm{H}_{2} \mathrm{O}$ maintained for $5 \mathrm{~min} ; 20 \% \mathrm{MeCN} / \mathrm{H}_{2} \mathrm{O}$ to $100 \%$ $\mathrm{MeCN}$ over $30 \mathrm{~min}$, then $100 \% \mathrm{MeCN}$ maintained for $15 \mathrm{~min}$; UV $254 \mathrm{~nm}$ ) to afford $1.5 \mathrm{mg}$ of pure alismol (colorless, amorphous solid). HPLC separation was carried out on a Thermo Scientific Dionex ${ }^{T M}$ UltiMate $^{T M}$ 3000 series system equipped with a DAD-3000RS rapid separation diode array detector, and a Thermo Scientific Dionex Corona ${ }^{T M}$ ultra $R S^{T M}$ Charged Aerosol Detector.

\section{Qualitative Analysis by Gas Chromatography/Mass} Spectrometry

Constituents of Peperomia borbonensis EO were analyzed by gas chromatography/mass spectrometry (GC/ MS) using a Hewlett Packard 6890-5973 instrument. The sample was analyzed on a non-polar SPB-5 capillary column $(60 \mathrm{~m} \times 0.32 \mathrm{~mm}$ i.d.; $0.25 \mu \mathrm{m}$ film thickness). The injector and the transfer line were both programmed to $250^{\circ} \mathrm{C}$. The oven temp. was programmed from $60^{\circ} \mathrm{C}$ to $250{ }^{\circ} \mathrm{C}$ at a rate of $4^{\circ} \mathrm{C} / \mathrm{min}$ and maintained at $250{ }^{\circ} \mathrm{C}$ for $50 \mathrm{~min}$. Helium was used as the carrier gas with a flow of $0.7 \mathrm{ml} / \mathrm{min}$. The mass detector was operated at $70 \mathrm{eV}$ in the El mode over the $\mathrm{m} / \mathrm{z}$ range $20-400 \mathrm{amu}$. The analysis was done using a 1:50 split ratio (injection volume $0.02 \mu \mathrm{l}$ of pure EO).

The retention indices of all the constituents were determined by the Kovats method using $n$-alkanes as standards. A mixture of $n$-alkanes $\left(C_{8}-C_{22}\right)$ was prepared from the pure chemicals at a $5 \%$ concentration in pentane. Constituents of the volatile oil were identified by comparison of their retention indices and their mass spectral fragmentation pattern with those reported in the literature ${ }^{[24]}$ and stored on MS Libraries (Wiley 7, NIST 02).
Quantitative Analysis by Gas Chromatography Flame Ionization Detector

Gas chromatography analysis of Peperomia borbonensis EO was carried out using a Varian Gas chromatograph (Model CP-3800-Star Chromatography Workstation) equipped with a flame ionization detection (FID) system and a non-polar SPB-5 capillary column (60 $\mathrm{m} \times 0.32 \mathrm{~mm}, 0.25 \mu \mathrm{m}$ film thickness). The oven temp. was programmed from $60^{\circ} \mathrm{C}$ to $250{ }^{\circ} \mathrm{C}$ at a rate of $4{ }^{\circ} \mathrm{C} / \mathrm{min}$ and maintained at $250{ }^{\circ} \mathrm{C}$ for $50 \mathrm{~min}$. Nitrogen was used as the carrier gas at a flow rate of $0.7 \mathrm{ml} / \mathrm{min}$. The sample was injected in splitless mode (injection volume $0.02 \mu \mathrm{l}$ of pure EO). The quantification of the components was performed on the basis of the GC peak area without response factor correction.

\section{NMR Analysis}

${ }^{1} \mathrm{H}$ - and ${ }^{13} \mathrm{C}$-NMR spectra were recorded in $\mathrm{CDCl}_{3}$ on a Bruker Avance $1 I^{+} 600$ spectrometer operating at $600 \mathrm{MHz}\left({ }^{1} \mathrm{H}\right)$ and $150 \mathrm{MHz}\left({ }^{13} \mathrm{C}\right)$ with chemical shifts reported in $\mathrm{ppm}(\delta)$ relative to TMS as internal standard.

\section{Bactrocera cucurbitae Bioassays}

Insects. An experimental population of B. cucurbitae was obtained from the pupae of wild flies collected in June $\mathbf{2 0 0 0}$ from infested fruits. Then, mass rearing was routinely carried out in the Cirad facilities under controlled conditions: $25 \pm 2{ }^{\circ} \mathrm{C}, 70 \pm 20 \%$ relative humidity and a 12:12 h (light:dark) photoperiod. The flies were given free access to granulated sugar, enzymatic yeast hydrolysate (ICN Biomedicals, Aurora, $\mathrm{OH})$ and water. Adult insects ( 15 - 19 days old) were used for toxicity bioassays.

Toxic Activity of P. borbonensis EO on B. cucurbitae. The toxic activity of $P$. borbonensis EO against adult flies was determined by a modified version of the impregnated filter paper technique. ${ }^{[18]}$ Appropriate amounts of EO were dissolved in acetone (see below), then $300 \mu \mathrm{l}$ of each mixture were applied to filter paper placed in a Petri dish $(9 \mathrm{~cm}$ diameter $\times 1.5 \mathrm{~cm}$ height). After the evaporation of acetone, 20 unsexed flies were anesthetized using $\mathrm{CO}_{2}$ and deposited into each Petri dish. To encourage contact between flies and the compounds, we placed an artificial light (neon) under the filter side and black paper on the other side. Insects were observed and considered $\mathrm{dead} / \mathrm{knocked}$ down when they were on 
their back and immobile. Acetone alone was used as the negative control. To establish the lethal concentrations of EO $\left(L C_{50}\right.$ and $\left.L C_{90}\right)$, the following range of dilutions in acetone was used: $1.89 \mathrm{mg} / \mathrm{cm}^{2}$, $0.94 \mathrm{mg} / \mathrm{cm}^{2}, \quad 0.71 \mathrm{mg} / \mathrm{cm}^{2}, \quad 0.47 \mathrm{mg} / \mathrm{cm}^{2}, \quad 0.35 \mathrm{mg} /$ $\mathrm{cm}^{2}, 0.24 \mathrm{mg} / \mathrm{cm}^{2}, 0.12 \mathrm{mg} / \mathrm{cm}^{2}, 0.06 \mathrm{mg} / \mathrm{cm}^{2}$, and $0.03 \mathrm{mg} / \mathrm{cm}^{2}$. Each concentration was repeated three times. The death of insects was recorded $180 \mathrm{~min}$ after treatment and the death rate was calculated.

Comparative Toxicity of EO and Major Constituents Alone or in the Mixture. The modified impregnated filter paper technique described above was used to determine the relative contribution of myristicin and elemicin to the overall toxicity. Myristicin (97.5\%) was purchased from Extrasynthese (Gennay, France) and elemicin (95\%) from Carbosynth (England). For this experiment, an EO concentration of $0.35 \mathrm{mg} / \mathrm{cm}^{2}$ was used as it was previously shown to be the lowest concentration to induce $100 \%$ mortality at the end of the experiment. To allow for a comparison between insecticidal activities, the amount of myristicin and elemicin used alone or in the mixture was fixed according to the ratio in the EO obtained by GC-FID: $0.14 \mathrm{mg} / \mathrm{cm}^{2}$ of myristicin (39.5\%) and $0.09 \mathrm{mg} / \mathrm{cm}^{2}$ of elemicin (26.6\%). The death of insects was recorded every $15 \mathrm{~min}$. Insects were considered dead when they were on their back and immobile. Three replicates were used for each product.

\section{Statistical Analysis}

Data were modeled to a binomial regression analysis with a logit function. ANOVA with a chi-squared test was used to compare modality between them. From this model, we generated values for the lethal concentrations $\left(L C_{50}\right.$ and $\left.L C_{90}\right)$ expressed in $\mathrm{mg} / \mathrm{cm}^{2}$ for the EO. The median lethal time $L T_{50}(\mathrm{~min})$ was calculated for the EO at $0.35 \mathrm{mg} / \mathrm{cm}^{2}$ and for the two major components (separately or in combination) at the concentrations described above according to their ratio in the EO. ${ }^{[50]}$ Tukey's all paired comparison tests (multicomp package) ${ }^{[51]}$ were used if the chi-squared test was significant. All tests were conducted at the significance level of 0.05 . The mortality induced by the two major products and the mixture were compared. The Wilcoxon signed rank test was used to compare, at different exposure times, the theoretical sum of the mortality ratio of the two major products tested separately and the observed mortality ratio of the mixture of them in order to reveal possible synergy or antagonism. The statistical software used was R Core Team. ${ }^{[52]}$

\section{Acknowledgements}

The authors gratefully acknowledge financial support from the European Commission and the Regional Council of Réunion Island through the BIOMOL-TCN Program (Activités Thérapeutiques, Cosmétologiques et Nutraceutiques de MOLécules issues de la BIOdiversité terrestre, marine et microbienne de la zone Sud-Ouest de I'Océan Indien) and ERDF (European Regional Development Fund, Grant No. 2012-326). The authors are very grateful to G. Begue and J. Fournel (UMR C_53 PVBMT) for their contributions to species collection and plant material identification. We would also like to acknowledge C. Ajaguin-Soleyen for the technical assistance, $D$. Muru and T. Schmitt for their collaboration on the insecticidal assays and all students who contributed to this work, especially S. Corré for methodological aspects.

\section{References}

[1] J.-P. Deguine, P. Ferron, Russell, Editions Quae, 2008.

[2] M. Wink, Oxford, UK, Wiley-Blackwell, 2010.

[3] O. Koul, S. Walia, G. S. Dhaliwal, Biopestic Int. 2008, 4, 63.

[4] F. Bakkali, S. Averbeck, D. Averbeck, M. Idaomar, Food Chem. Toxicol. 2008, 46, 446.

[5] J. R. Calo, P. G. Crandall, C. A. O'Bryan, S. C. Ricke, Food Control 2015, 54, 111.

[6] C. Regnault-Roger, C. Vincent, J. T. Arnason, Ann. Rev. Entomol. 2012, 57, 405.

[7] S. Zoubiri, A. Baaliouamer, J. Saudi Chem. Soc. 2011, 18, 925.

[8] E. Enan, Comp. Biochem. Physiol., Part C: Toxicol. Pharmacol. 2001, 130, 325.

[9] L. G. Felippe, D. C. Baldoqui, M. J. Kato, V. S. da Bolzani, E. F. Guimarães, R. M. B. Cicarelli, M. Furlan, Phytochemistry 2008, 69, 445.

[10] M. F. de Arrigoni-Blank, E. G. Dmitrieva, E. M. Franzotti, A. R. Antoniolli, M. R. Andrade, M. Marchioro, J. Ethnopharmacol. 2004, 91, 215.

[11] A. Khan, M. Rahman, S. Islam, Turk. J. Biol. 2008, 32, 37.

[12] M. R. Khan, A. D. Omoloso, Fitoterapia 2002, 73, 251.

[13] P. Ryckewaert, J.-P. Deguine, T. Brévault, J.-F. Vayssières, Fruits 2010, 65, 113.

[14] I. M. White, M. M. Elson-Harris, Wallingford, Oxon, UK, CAB International in association with ACIAR, 1992.

[15] J.-P. Deguine, T. Atiama-Nurbel, J.-N. Aubertot, X. Augusseau, M. Atiama, M. Jacquot, B. Raynaud, Agron. Sustain. Dev. 2015, 5, 937.

[16] M. K. Dhillon, R. Singh, J. S. Naresh, H. C. Sharma, J. Insect. Sci. 2005, 6, 5.

[17] S. B. López, M. L. López, L M. Aragón, M. L. Tereschuk, A. C. Slanis, G. E. Feresin, J. A. Zygadlo, A. A. Tapia, J. Agric. Food Chem. 2011, 59, 5286.

[18] G. Benelli, A. Canale, G. Flamini, P. L. Cioni, F. Demi, L. Ceccarin, M. Macchiac, B. Contia, Ind. Crops Prod. 2013, 50, 596. 
[19] G. Benelli, G. Flamini, A. Canale, P. L. Cioni, B. Conti, Crop Prot. 2012, 42, 223.

[20] C. L. Chang, I. K. Cho, Q. X. Li, J. Econ. Entomol. 2009, 102, 203.

[21] Y. Hidayat, N. Heather, E. Hassan, Postharvest Biol. Technol. 2015, 110, 166.

[22] S. Rampadarath, D. Puchooa, V. M. Ranghoo-Sanmukhiya, Asian Pac. J. Trop. Med. 2014, 7, S384.

[23] A. Kaur, S. K. Sohal, R. Singh, S. Arora, J. Biopest. 2010, 3, 499 - 504.

[24] R. P. Adams, 'Identification of essential oil components by gas chromatography/quadrupole mass spectroscopy', 3rd edn., Carol Stream, IL, Allured Publishing, 2001.

[25] J. Xu, D. Jin, D. Shi, Y. Ma, B. Yang, P. Zhao, Y. Guo, Fitoterapia 2011, 82, 508.

[26] J. H. G. Lago, A. Oliveira, E. F. Guimarães, M. J. Kato, J. Braz. Chem. Soc. 2007, 18, 638.

[27] P. R. D. Santos, D. L. de Moreira, E. F. Guimarães, M. A. C. Kaplan, Phytochemistry 2001, 58, 547.

[28] P. D. L. Lira, Y. Farfan, C. M. V. Baren, A. L Bandoni, J. D. Coussio, A. P. D. Abram, Rev. Latinoam. Quim. 2007, 35, 7.

[29] M. G. B. Zoghbi, E. H. A. Andrade, R. C. L Lobato, A. C. C. Tavares, A. P. S. Souza, C. C. C. Conceição, E. F. Guimarães, Biochem. Syst. Ecol. 2005, 33, 269.

[30] D. L Moreira, P. O. de Souza, M. A. C. Kaplan, E. F. Guimarães, Acta Hort. 1999, 65.

[31] M. H. L. da Silva, M. D. G. B. Zoghbi, E. H. A. Andrade, J. G. S. Maia, Flavour Fragrance J. 1999, 1, 312.

[32] P. N. B. de Lira, J. K. R. da Silva, E. H. A. Andrade, P. J. Sousa, N. N. S. Silva, J. G. S. Maia, Nat. Prod. Commun. 2009, 4, 427.

[33] S. llyas, S. Naz, F. Aslam, Z. Parveen, A. Ali, Pak. J. Bot. 2014, 46, 667.

[34] F. Tchoumbougnang, P. M. Jazet Dongmo, A. V. Wouatsa Nangué, F. Fekam Boyom, M. L. Sameza, P. H. Amvam Zollo, C. Menut, J. Essent. Oil Bear. PI. 2013, 16, 679.

[35] S. M. de Morais, V. A. Facundo, L. M. Bertini, E. S. B. Cavalcanti, J. F. dos Anjos Júnior, S. A. Ferreira, S. E. de Brito, A. M. de Souza Neto, Biochem. Syst. Ecol. 2007, 35, 670.
[36] W. Qin, S. Huang, C. Li, S. Chen, Z. Peng, Pestic. Biochem. Physiol. 2010, 96, 132.

[37] H.-J. Yeom, C.-S. Jung, J. Kang, J. Kim, J.-H. Lee, D.-S. Kim, P.-S. Park, K.-S. Kang, I.-K. Park, J. Agric. Food Chem. 2015, 63, 2241.

[38] S. S. Chu, G. H. Jiang, Z. L Liu, Pest Manag. Sci. 2011, 67, 1253.

[39] M. D. López, M. J. Pascual-Villalobos, Flavour Fragrance J. 2015, 30, 108.

[40] C.-F. Wang, K. Yang, C.-X. You, W.-J. Zhang, S.-S. Guo, Z.-F. Geng, S.-S. Du, Y.-Y. Wang, Molecules 2015, 20, 7990.

[41] P. K. Mukherjee, V. Kumar, M. Mal, P. J. Houghton, Phytomedecine 2007, 14, 289.

[42] Y. Kashima, H. Yamaki, T. Suzuki, M. Miyazawa, J. Agric. Food Chem. 2011, 59, 7114.

[43] B. K. Lee, J. H. Kim, J. W. Jung, J. W. Choi, E. S. Han, S. H. Lee, K.-H. Ko, J.-H. Ryu, Toxicol. Lett. 2005, 157, 49.

[44] U. Stein, H. Greyer, H. Hentschel, Forensic Sci. Int. 2001, $118,87$.

[45] C. B. Bernard, H. G. Krishanmurty, D. Chauret, T. Durst, B. J. R. Philogène, P. Sánchez-Vindas, C. Hasbun, L. Poveda, L. San Raman, J. T. Arnason, J. Chem. Ecol. 1995, 21, 801.

[46] I. M. Scott, H. R. Jensen, B. J. R. Philogène, J. T. Arnason, Phytochem. Rev. 2008, 7, 65.

[47] K. Swiech, I. Polec, Chemik 2013, 67, 1115.

[48] E. P. Lichtenstein, J. E. Casida, J. Agric. Food Chem. 1963, $11,410$.

[49] T. Atiama-Nurbel, J.-P. Deguine, S. Quilici, Arthropod-Plant Interact. 2012, 6, 395.

[50] W. N. Venables, B. D. Ripley, 'Modern Applied Statistics with S', 4th edn, New York, Springer, 2002.

[51] T. Hothorn, F. Bretz, P. Westfall, Biometrical J. 2008, 50, 346.

[52] R Development Core Team, 2015. 